\title{
Clonal groups of enteropathogenic Escherichia coli isolated in case-control studies of diarrhoea in Bangladesh
}

\author{
M. ANSARUZZAMAN, M. J. ALBERT, S. NAHAR, R. BYUN, M. KATOULI*, I. KÜHN* and \\ R. MÖLLBY*
}

International Centre for Diarrhoeal Disease Research, Bangladesh, Dhaka, Bangladesh and *Microbiology and Tumorbiology Centre, Karolinska Institute, Stockholm, Sweden

\begin{abstract}
Recent case-control studies in Bangladesh showed a high prevalence of enteropathogenic Escherichia coli (EPEC) strains (identified by DNA probes for virulence genes) associated with childhood diarrhoea. However, the clonal status of these strains is not known. A total of 94 EPEC isolates from 80 children with diarrhoea and 14 healthy matched controls isolated during 1991-1992 and 1993-1994 was characterised by serogrouping, enterobacterial repetitive intergenic consensus sequence PCR, and by a biochemical fingerprinting method (the phene plate or PhP system). Twelve 0 serogroups were found with $0114(n=19)$ and $0127(n=23)$ being the dominant serogroups. M ost strains of 0114 belonged to the same PhP/PCR types. Strains of 0127 contained 16 that produced cytolethal distending toxin (CDT) and seven that did not; both were found among patients as well as controls. Results of PCR and PhP typing showed that CDT-positive strains belonged to the same clonal group and were related to one of the two PhP/PCR types of CDT-negative 0127 strains. Thirty-one EPEC strains were $O$ non-typable and 21 strains belonged to other less prevalent serogroups. These strains belonged to diverse PhP/PCR types and did not show any similarity to the strains of two major serogroups, 0114 and 0127 . The results suggest that two clonal groups of EPEC strains are predominantly associated with childhood diarrhoea in Bangladesh.
\end{abstract}

\section{Introduction}

Diarrhoea is one of the most common causes of morbidity and mortality among infants and young children in developing countries, with Escherichia coli being one of the major causative agents [1-3]. Intensive studies have shown the presence of several classes of diarrhoea-producing E. coli, each characterised by a number of pathogenic properties. These include enteropathogenic E. coli (EPEC) [4-7], enterotoxigenic $E$. coli (ETEC) [8], enteroinvasive E. coli (EIEC) [9], enterohaemorrhagic E. coli (EHEC) [10], diffuse adherent $E$. coli (DAEC) and enteroaggregative $E$. coli $(E A g g E C)[9,11]$. The prevalence of each of these types varies between countries $[5,12,13]$.

Received 9 Feb. 1999; revised version received 22 June 1999; accepted 11 July 1999.

Corresponding author: Dr M. Katouli (e-mail: mkatouli@ usc.edu.au). Present address: Faculty of Science, University of the Sunshine Coast, Maroochydore DC, Queensland 4558, A ustralia.
Although EPEC was the first category of diarrhoeaproducing $E$. coli to be identified in the early part of this century, their pathogenic mechanisms have been elucidated only recently. The classical method for identification of EPEC strains is serotyping. This method has served as the main diagnostic tool for many years and up to 12 serogroups have been recognised as the traditional EPEC serogroups [11]. However, the development of DNA probes and cell culture assays has reduced the dependence on serotyping alone for identification of EPEC strains $[4,14,15]$. With these newly developed techniques and in combination with 0 -serogrouping, many workers have investigated the prevalence of EPEC strains among infants and young children with diarrhoea in different countries $[8,16]$.

A new toxin, named cytolethal-distending toxin (CDT) has been identified among several enteropathogenic bacteria, including EPEC strains [17]. In two recent studies $[16,18]$ on the aetiology of childhood diarrhoea in Bangladesh, EPEC have been identified as a leading 
cause of bacterial diarrhoea in infants, with some strains also producing CDT [18]. In view of the above findings, the present study was done to investigate the clonal status of EPEC strains isolated from these casecontrol studies in Bangladesh.

\section{$M$ aterials and methods}

EPEC isolates

The EPEC isolates were from two studies conducted at the Dhaka Treatment Centre of the International Centre for Diarrhoeal Disease Research, Bangladesh (ICDDR, B). In the first study, conducted during July 1991- May 1992 [16], the prevalence of diarrhoeagenic E. coli, including EPEC, was investigated in 451 children up to 5 years of age with diarrhoea, and in 602 matched control children without diarrhoea. EPEC were identified by hybridisation of $E$. coli colonies with DNA probes for EPEC adherence factor (EAF) and attaching and effacing $(A E)$ factor. Colonies that were hybridisation-positive with both probes or with the $A E$ probe only were considered to be EPEC. In that study, EPEC strains were isolated from $70(15.3 \%)$ patients with diarrhoea and $33(5.3 \%)$ controls, thus showing a significant association $(p<0.0001)$ with diarrhoea.

The second study consisted of 546 children up to 5 years of age, with diarrhoea, attending the same centre at the ICDDR, B during July 1993-M ay 1994. The control group consisted of 215 matched healthy children. In that study, EPEC were identified by DNA probe hybridisation assay as in the first study. In addition, cytolethal-distending toxin (CDT)-producing $E$. coli were identified by a DNA probe hybridisation assay and tissue culture assay. CDT $+E$. coli were isolated from $17(3.1 \%)$ patients and two $(0.93 \%)$ controls $(p=0.082)$. The isolates from 13 patients and the controls were available for serotyping, and all of them belonged to the serotype $0127: \mathrm{H}^{-}$[18]. All the 15 isolates from the second study and the seven 0127 isolates from the first study were included in the present study. A summary of the isolates tested in the present study is shown in Table 1.

\section{Enterobacterial repetitive intergenic consensus (ERIC) PCR}

Bacterial DNA was prepared by directly picking colonies from $\mathrm{M}$ acConkey agar plates and lysing them in de-ionised water by boiling for $5 \mathrm{~min}$. The supernate was used as the template DNA for PCR. A mplification was performed with a DNA thermal cycler (PerkinEImer DNA thermal cyclers, Norwalk, CT, USA) under the following conditions: 25 cycles of $30 \mathrm{~s}$ at $94^{\circ} \mathrm{C}$, $30 \mathrm{~s}$ at $36^{\circ} \mathrm{C}$ and $90 \mathrm{~s}$ at $72^{\circ} \mathrm{C}$ with $3 \mathrm{~min}$ initial denaturation at $94^{\circ} \mathrm{C}$ and a 10 -min final extension at $72^{\circ} \mathrm{C}$, with a $50-\mu \mathrm{l}$ volume containing $5 \mu \mathrm{l}$ of bacterial DNA and 0.75 unit of Taq DNA polymerase (Gibco$B R L$ ) in a buffer containing $25 \mathrm{~mm} \mathrm{MgCl}, 200 \mathrm{~mm}$
Table 1. Enteropathogenic E. coli (EPEC) isolates included in the present study from the previous two case-control studies of diarrhoea in Bangladesh

\begin{tabular}{llccc}
\hline \multirow{2}{*}{$\begin{array}{l}\text { Study } \\
\text { no. }\end{array}$} & Serogroup & patients & controls & $\begin{array}{c}\text { Notal number } \\
\text { of }\end{array}$ \\
\cline { 2 - 4 } isolates
\end{tabular}

EPEC were identified by DNA probe hybridisation. The first study was conducted during July 1991-M ay 1992, on 451 patients and 602 controls [16]; the second during July 1993-M ay 1994 on 546 patients and 215 controls [18]. From the second study only CDTpositive EPEC were included. ONT, 0 antigen non-typable.

Tris- $\mathrm{HCl}(\mathrm{pH} 8.4), 500 \mathrm{~mm} \mathrm{KCl}, 10 \mathrm{~mm}$ each of dATP, dCTP, dGTP and dTTP, and $0.25 \mathrm{~mm}$ primer. The primer was based on the enterobacterial repetitive consensus sequence (5'-ATGTAAGCTCCTGGGGATT(AC-3') [19]. After PCR amplification, samples of the products were electrophoresed in agarose $1 \%$ gel containing ethidium bromide $0.2 \mathrm{mg} / \mathrm{ml}$ and photographed under UV light. The gel-photos were scanned by a hand scanner and the reconstructed gel images were created and analysed with GelCompare software, version 4.0 (A pplied Maths, Kortrijk, Belgium). DNA fragment patterns generated by PCR were compared pairwise. Isolates with indistinguishable bands were regarded as identical and assigned to a common PCR type. These types were denoted by low-case letters (i.e., $a, b, c$, etc.). On the basis of differences in size and number of the fragments, isolates with PCR patterns similar to the common types were considered to be subtypes and were indicated by a number after the PCR-designated letter (i.e., subtype of PCR type $a$ is a1). Isolates with PCR patterns distinctly different $(<50 \%$ fragments in common) from other types were regarded as non-related or single (si) PCR types [20].

\section{Biochemical fingerprinting}

E. coli strains were typed on the basis of their biochemical phenotypes by the Phene Plate (PhP) system specifically developed for typing E. coli strains (PhPlate Stockholm AB, Sweden). Briefly, a loopful of a fresh culture of bacteria was suspended in $8 \mathrm{ml}$ of sterile proteose-peptone $0.1 \% \mathrm{w} / \mathrm{v}$ solution containing bromothymol blue $0.11 \% \mathrm{w} / \mathrm{v}$ and $150-\mu \mathrm{l}$ volumes of the suspensions were inoculated into 24 wells in preprepared microtitration plates. Plates were stored at $4^{\circ} \mathrm{C}$ overnight and incubated at $37^{\circ} \mathrm{C}$ the following morning. 
The $A_{620}$ of each reaction was measured at 7, 24 and $48 \mathrm{~h}$ with a microplate reader and the data were automatically transferred to a personal computer, multiplied by 10 , yielding scores ranging from 0 to 30 for each reaction. A fter the final reading, the mean value of all readings was calculated resulting in 24 different numbers ranging from 0 to 30 for each strain (the biochemical fingerprint). Similarities between the strains were calculated as correlation coefficients as described before [21] and clustered according to the unweighted pair group method with arithmetic averages (UPGMA) [22] yielding a dendrogram. An identity level of 0.975 was set based on reproducibility of the system as described before [23]. Strains showing similarities to each other higher than this value were regarded as identical and assigned to the same PhP types and those not identical to any other isolates were called single (Si) PhP types. Different PhP types were denoted by capital letters and those non-identical types belonging to the same cluster were denoted by the same capital letters followed by different numbers.

Phenotypic diversity of the bacterial populations within each serogroup was measured as Simpson's index of diversity (Di) [24]. Within each serogroup, biochemical homogeneity among the bacterial population was calculated as the mean of correlation coefficient between all isolates.

\section{Comparison between typing methods}

The agreement between the typing methods was measured as described earlier [25]. B riefly, the diversity of isolates was calculated by both typing methods. $M$ embers of each pair of isolates, which were either identical or different by both typing methods, yielded a score of +1 (which indicates a good agreement). Members of each pair, which were identical by the typing method showing the lowest diversity and different by the method showing the highest diversity, also yielded a score of +1 (good agreement). Finally, members of each pair, which were different by the typing method showing the lowest diversity and identical by the method showing the highest diversity, were given score of -1 (poor agreement). The sum of all scores was calculated and divided by the number of comparisons. By multiplying this value by 100 , a value which is an estimate of the percentage agreement between two typing methods was obtained.

\section{Statistical analysis}

The $\chi^{2}$ test was used for measuring the significance of differences.

\section{R esults}

The most common serogroups among the EPEC strains studied were 0127 and 0114 . Of the 23 EPEC strains belonging to serogroup 0127, 16 produced CDT. Results of both the PhP typing and the PCR typing indicated that most of these strains belonged to one common clonal group (i.e., PhP/PCR type $\mathrm{C} / \mathrm{b}$ ) (Fig. 1). The CDT-negative strains belonged to two different PhP/PCR types, one of which was closely related to CDT-positive strains (Fig. 1). To investigate the degree of relationship among these strains, phenotypic diversity and homogeneity were measured among them. A low diversity was found with both typing methods (i.e., 0.71 and 0.49 for PhP and PCR, respectively). There was also a high homogeneity (i.e., 0.78) among their biochemical phenotypes (Table 2).

Sixteen of the 19 strains of serogroup 0114 belonged to the same PhP/PCR type (Fig. 2), thus showing a low diversity with both the PhP (0.30) and the PCR (0.30) typing methods, and a high homogeneity (0.87) with respect to their biochemical phenotypes (Table 2). A high agreement was obtained between the PhP and the PCR typing methods for strains of serogroups 0127 (99\%) and $0114(100 \%)$ (Table 2). According to both typing methods, EPEC strains belonging to less common serogroups $(n=21)$ also belonged to many different clonal groups, although within certain serogroups there was a high similarity between the strains. For example, all five strains belonging to serogroup 0125 had very similar PhP/PCR types. Similarly, three of the four strains belonging to serogroup 020 also had similar $\mathrm{PhP} / \mathrm{PCR}$ types (Fig. 3). It was also found that some strains belonging to different serogroups (e.g., 020 and 0126) had identical PhP or PCR types, or both (Fig. 3).

The 0 antigen non-typable (ONT) strains $(n=31)$ were also highly diverse as shown by both methods, although some clusters of strains with similar PhP and PCR types were found (Fig. 4). For example, strains belonging to PhP types $K$ and $L$ (including $L 1$ ) had similar PCR types (i.e., $h$ and g, including $g 1$ and g2, respectively) (Fig. 4). A gain, isolates were found with different PhP types that had similar PCR types (e.g., PCR type e) (Fig. 4).

To find out whether ONT strains have originated from any of the known 0 serogroups, one isolate from each common and single PhP/PCR type shown in Figs. 1-3 was selected and compared with the ONT strains (Fig. 5). The results indicated that while only a few ONT strains were identical to strains of known serogroups (e.g., strains of PhP types N and L), most of the ONT strains were distantly related to each other and to the strains of known serogroups (Fig. 5). It was also found that strains with known serogroups were more related to each other than ONT strains.

\section{Discussion}

Infection due to EPEC continues to be a major cause of infantile diarrhoea in developing countries $[8,26]$. 


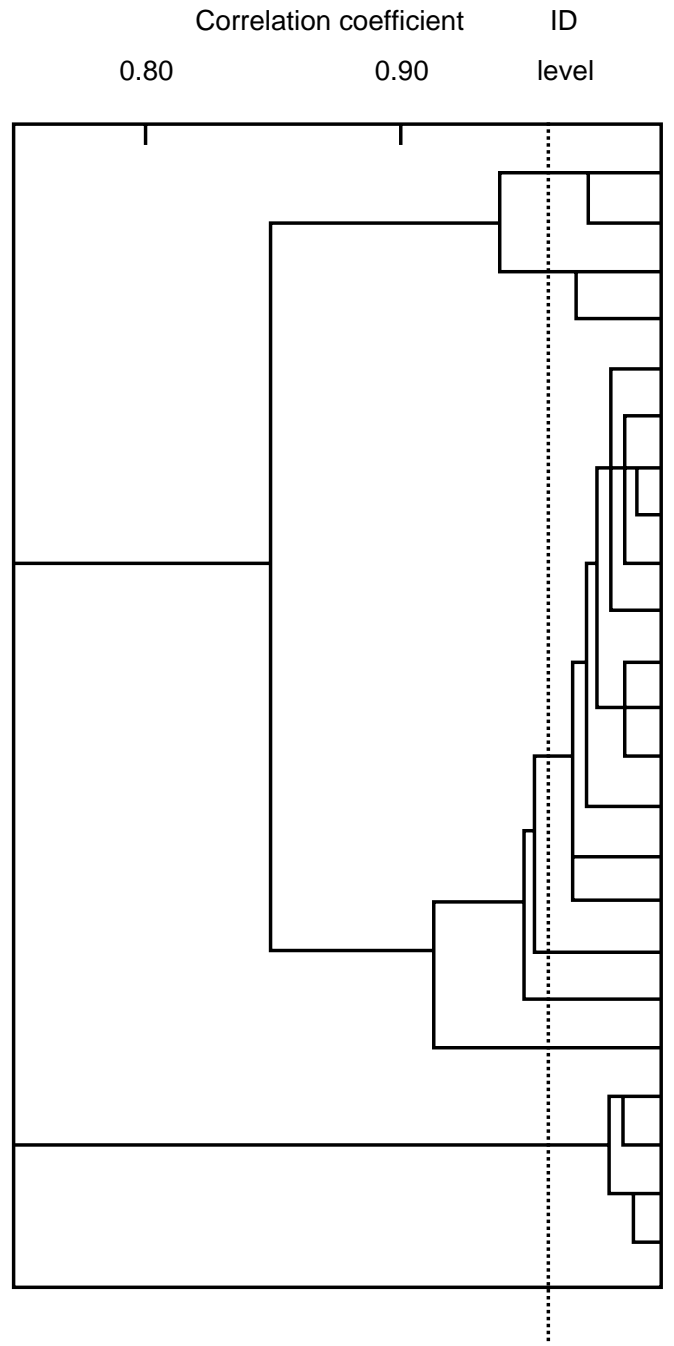

PhP PCR
type

CDT Source

PCR

\section{A b2 $\quad-\quad n$}

$\begin{array}{llll}A & b 1 & - & D\end{array}$

$\begin{array}{llll}\text { B } & b & - & D\end{array}$

B $b+$ D

C $\quad$ b1 $+\quad$ D

C $b+$ D

C $b+$ D

C b1 + D

C b + D

C $\quad b \quad+\quad$ D

C b1 + D

C $b+$ D

C $b+$ D

C $\quad$ b1 + D

C $b+$ D

C $b+$ D

$\begin{array}{llll}\text { C1 } & b 1+ & \text { D }\end{array}$

C2 $b+$ D

C3 $b+\quad$ D

D $\quad f \quad-\quad$ D

$\begin{array}{lllll}\text { D } & \mathrm{f} & - & \mathrm{C}\end{array}$

D $\quad f \quad-\quad$ D

D $\quad f \quad-\quad$ D

Fig. 1. UPGMA dendrogram derived from clustering of the PhP types and their comparison with PCR types of EPEC strains belonging to serogroup 0127, isolated from case-control studies of diarrhoea in Bangladesh. CDT, cytolethal distending toxin; D, diarrhoeal cases; C, healthy control; ID level, identity level.

Table 2. Diversity and homogeneity of isolates within different serogroups and the agreement among the three typing methods used for 94 EPEC isolates from two case-control studies of diarrhoeal disease in Bangladesh during 1991-1992 and 1993-1994

\begin{tabular}{|c|c|c|c|c|c|c|c|c|c|}
\hline \multirow{3}{*}{$\begin{array}{l}\text { EPEC } \\
\text { serogroup } \\
\text { (n) }\end{array}$} & \multirow{2}{*}{\multicolumn{2}{|c|}{ Diversity index }} & \multirow[b]{3}{*}{ Homogeneity } & \multicolumn{6}{|c|}{ A greement between } \\
\hline & & & & \multicolumn{3}{|c|}{ Serogroup and } & \multicolumn{2}{|c|}{$\mathrm{PhP}$ and } & \multirow{2}{*}{$\begin{array}{l}P C R \text { and } \\
\text { serogroup }\end{array}$} \\
\hline & $\mathrm{PhP}$ & PCR & & $\mathrm{PhP}$ & PCR & serogroup & PCR & serogroup & \\
\hline $\begin{array}{l}0127(23) \\
0114(19)\end{array}$ & $\begin{array}{l}0.76 \\
0.67\end{array}$ & $\begin{array}{l}0.49 \\
0.30\end{array}$ & $\begin{array}{l}0.78 \\
0.87\end{array}$ & $\begin{array}{l}0.76 \\
0.67\end{array}$ & $\begin{array}{l}0.49 \\
0.30\end{array}$ & $\begin{array}{l}\text { NA } \\
\text { NA }\end{array}$ & $\begin{array}{c}99 \% \\
100 \%\end{array}$ & $\begin{array}{l}\text { NA } \\
\text { NA }\end{array}$ & $\begin{array}{l}\text { NA } \\
\text { NA }\end{array}$ \\
\hline $\left.\begin{array}{l}0142 \\
0128 \\
0126 \\
0125\end{array}\right]$ & & & & & & & & & \\
\hline \begin{tabular}{r|r}
0119 \\
086 \\
044 \\
028 \\
020 \\
02
\end{tabular} & 0.98 & 0.94 & 0.56 & 0.98 & 0.93 & 0.90 & $100 \%$ & $98 \%$ & $98 \%$ \\
\hline ONT (31) & 0.99 & 0.99 & 0.59 & 0.99 & 0.99 & NA & $100 \%$ & NA & NA \\
\hline
\end{tabular}

NA, not applicable; ONT, 0 antigen non-typable. 


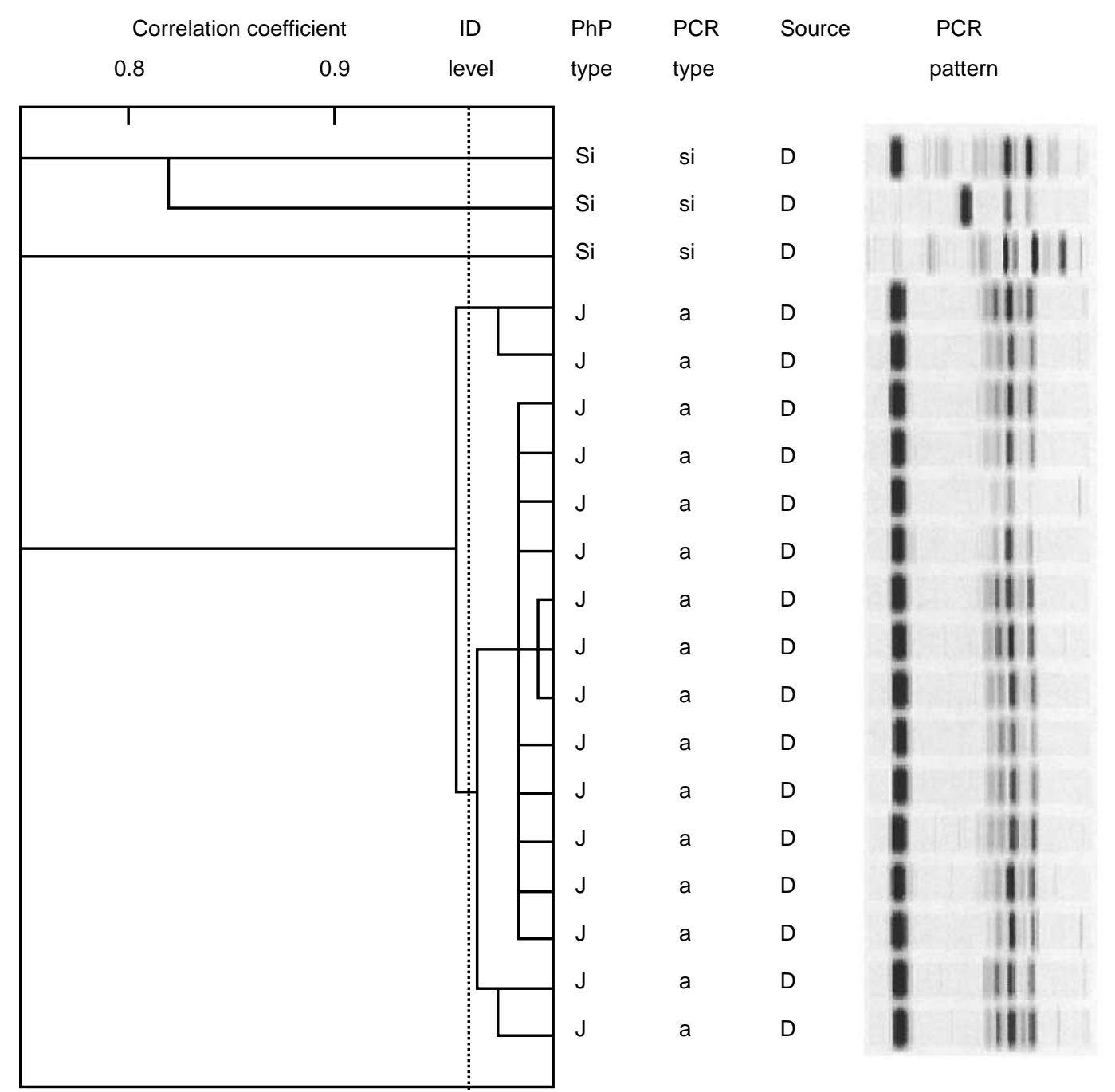

Fig. 2. UPGMA dendrogram derived from clustering of the PhP types and their comparison with PCR types of EPEC strains belonging to serogroup 0114, isolated from case-control studies of diarrhoea in Bangladesh. $D$, diarrhoeal cases; C, healthy controls; ID level, identity level; Si, PhP type found in only one isolate; si, PCR type found in only one isolate.

Studies of the clonal nature of EPEC strains still rely heavily on conventional serotyping in combination with different molecular techniques [27]. In the present study, serogrouping was used in combination with two other methods to characterise EPEC isolates. With similar techniques, several studies of the association of EPEC serogroups with infantile diarrhoea have shown that, in each geographical area, a few clonal groups are responsible for a majority of the infections [28-30]. The results of the present study not only showed the presence of two dominant serogroups of EPEC strains among diarrhoeal children in Bangladesh, but also indicated that the majority of the isolates belonged to just a few clonal groups.

M ost isolates of serogroup 0114 were related to each other according to the typing methods used, and may thus have had a common clonal origin. Strains of this serogroup have been traditionally recognised as class I EPEC [29] and are found infrequently in many countries. The division of the EPEC into classes I and II distinguishes strains with the EAF plasmid from those without the plasmid, i.e., class I EPEC contain both eaeA gene (which is responsible for AE lesions) and EAF plasmid, but strains of class II EPEC contain only the eaeA gene. The two clonal serogroups 0114 and 127 found in the present study both contained the eaeA gene and the EAF plasmid as identified by hybridisation with specific probes. Of interest also was the finding that most strains of the other common serogroup (0127) produced CDT. The toxin is so named because of the characteristic morphological changes that it produces on various cell lines. It causes initial elongation of the cells followed by progressive cellular distension and cytotoxicity. A controlled study of $C D T+E$. coli strains, from which isolates for the present study were obtained, found that although $C D T^{+} E$. coli strains were isolated from more children with diarrhoea than from healthy controls, the difference did not reach statistical significance [18]. Like many other toxin genes [31, 32], there is a possibility that cdt gene may lie within large regions of DNA 


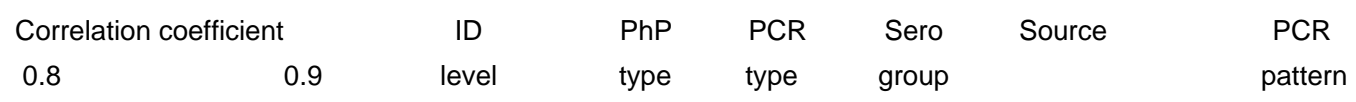

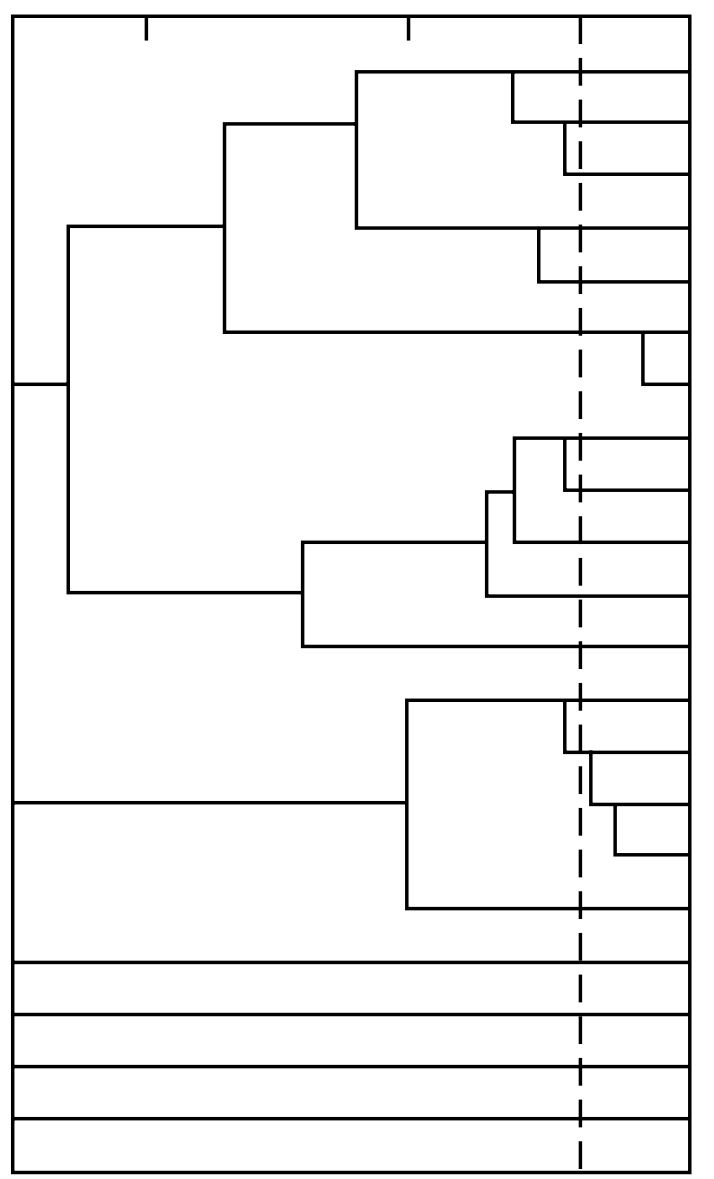

$\begin{array}{lll}\mathrm{Si} & \mathrm{n} & \mathrm{O} 126 \\ \mathrm{E} 1 & \mathrm{n} 1 & 0128 \\ \mathrm{E} 2 & \mathrm{n} 2 & 0119 \\ \mathrm{~F} 1 & \mathrm{n} 3 & 0142 \\ \mathrm{~F} 2 & \mathrm{n} & 0142 \\ \mathrm{G} & \mathrm{v} & \mathrm{O} 126 \\ \mathrm{G} & \mathrm{v} 1 & \mathrm{O} 20 \\ \mathrm{H} 1 & \mathrm{I} & \mathrm{O} 20 \\ \mathrm{H} 2 & \mathrm{I} & \mathrm{O} 20 \\ \mathrm{Si} & \mathrm{I} & \mathrm{O} 20 \\ \mathrm{Si} & \mathrm{si} & \mathrm{O} 44 \\ \mathrm{Si} & \mathrm{si} & \mathrm{O} 28 \\ \mathrm{I} 1 & \mathrm{C} & \mathrm{O} 125 \\ \mathrm{I} & \mathrm{C} & \mathrm{O} 125 \\ \mathrm{I} & \mathrm{C} & \mathrm{O} 125 \\ \mathrm{I} & \mathrm{C} & \mathrm{O} 125 \\ \mathrm{Si} & \mathrm{C} & \mathrm{O} 125 \\ \mathrm{Si} & \mathrm{si} & \mathrm{O} \\ \mathrm{Si} & \mathrm{si} & \mathrm{O} 126 \\ \mathrm{Si} & \mathrm{si} & \mathrm{O} 119 \\ \mathrm{Si} & \mathrm{si} & \mathrm{O} 2\end{array}$

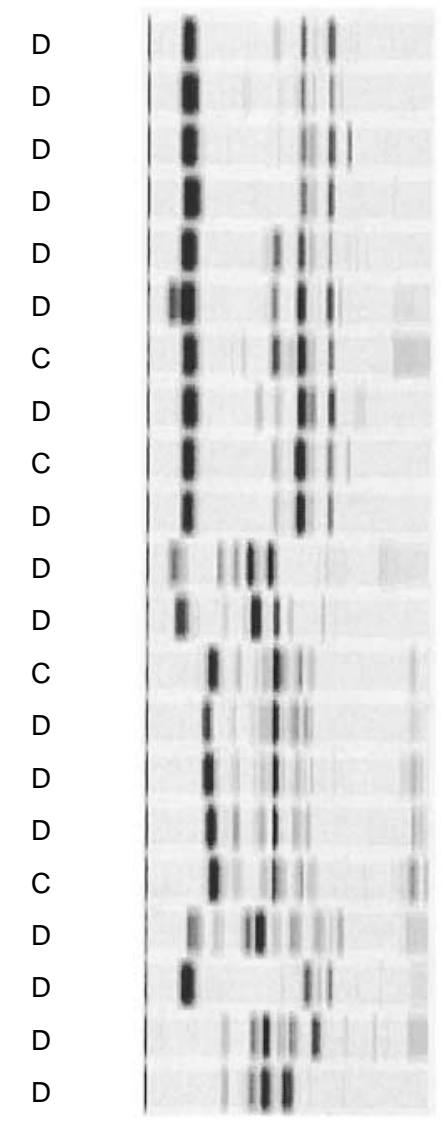

Fig. 3. UPGMA dendrogram derived from clustering of the PhP types and their comparison with PCR types of EPEC strains belonging to less prevalent serogroups isolated from case-control studies of diarrhoea in Bangladesh. $D$, diarrhoeal cases; C, healthy control; ID level, identity level; Si, PhP type found in only one isolate; si, PCR type found in only one isolate.

foreign to the E. coli chromosome. These regions are termed 'pathogenicity islands' which often harbour clustered virulence determinants, IS sequences and phage- or plasmid-like traits. These elements may act as vehicles for the horizontal transfer of virulence determinants giving rise to potential new pathogens [32]. The fact that $\mathrm{CDT}^{+}$strains in the present study had very similar PhP/PCR types to one of the two $\mathrm{CDT}^{-}$strains of the same serogroup suggests that $\mathrm{CDT}^{+}$strains might have evolved from $\mathrm{CDT}^{-}$strains by acquiring the cdt genes.

In determining the clonal origin of the EPEC isolates, a high agreement was found between the results obtained with all three typing methods used, although this was more pronounced with PhP and PCR typing than with either of these two methods and serogrouping. However, it should be noted that a good correlation between two typing methods does not necessarily mean that they are superior to other typing methods used in the same study, but simply implies that either method can be used when relations between the isolates are to be measured.
Twenty-one isolates belonging to other serogroups were also included in this study. Some of these serogroups belonged to class I EPEC and have been responsible for several outbreaks in different countries [33]. Results of the PhP typing indicated that they were highly diverse, sometimes even within a serogroup. For example, isolates belonging to 0126 contained three distinct PhP types. On the other hand, with the PCR typing method, these isolates yielded the same genotypical pattern. Again, there was a higher agreement between the PhP and the PCR typing methods than between either of these methods and serogrouping.

In the present study a high percentage of EPEC isolates was also found which were not typable with traditional EPEC antisera and other available antisera. These ONT strains belonged to highly diverse PhP/PCR types [16]. Determination of virulence properties by DNA probes and cell culture techniques has improved the potential to identify true EPEC strains (i.e., strains with EAF and AE properties) in epidemiological studies [33-36]. All non-typable strains tested in the present study were shown to be true EPEC strains as determined by 


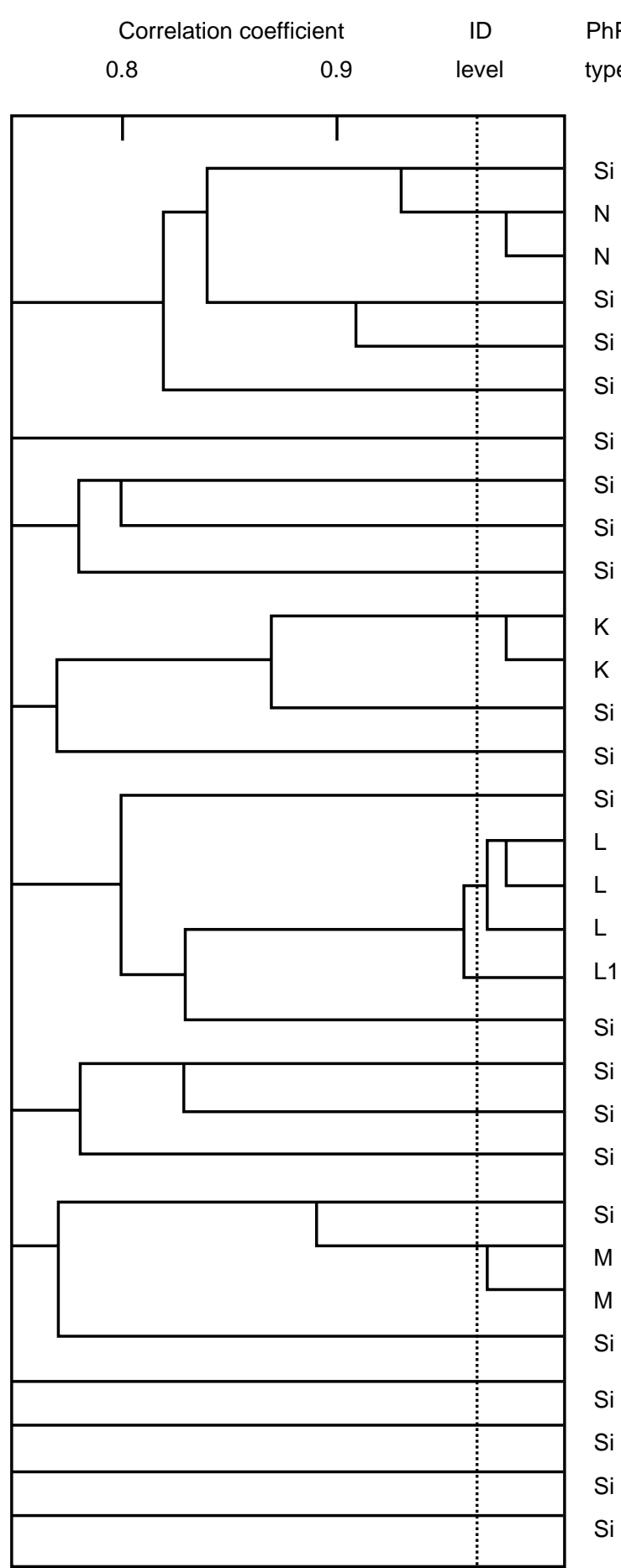

$$
\begin{aligned}
& \text { PCR Source PCR } \\
& \text { type pattern }
\end{aligned}
$$

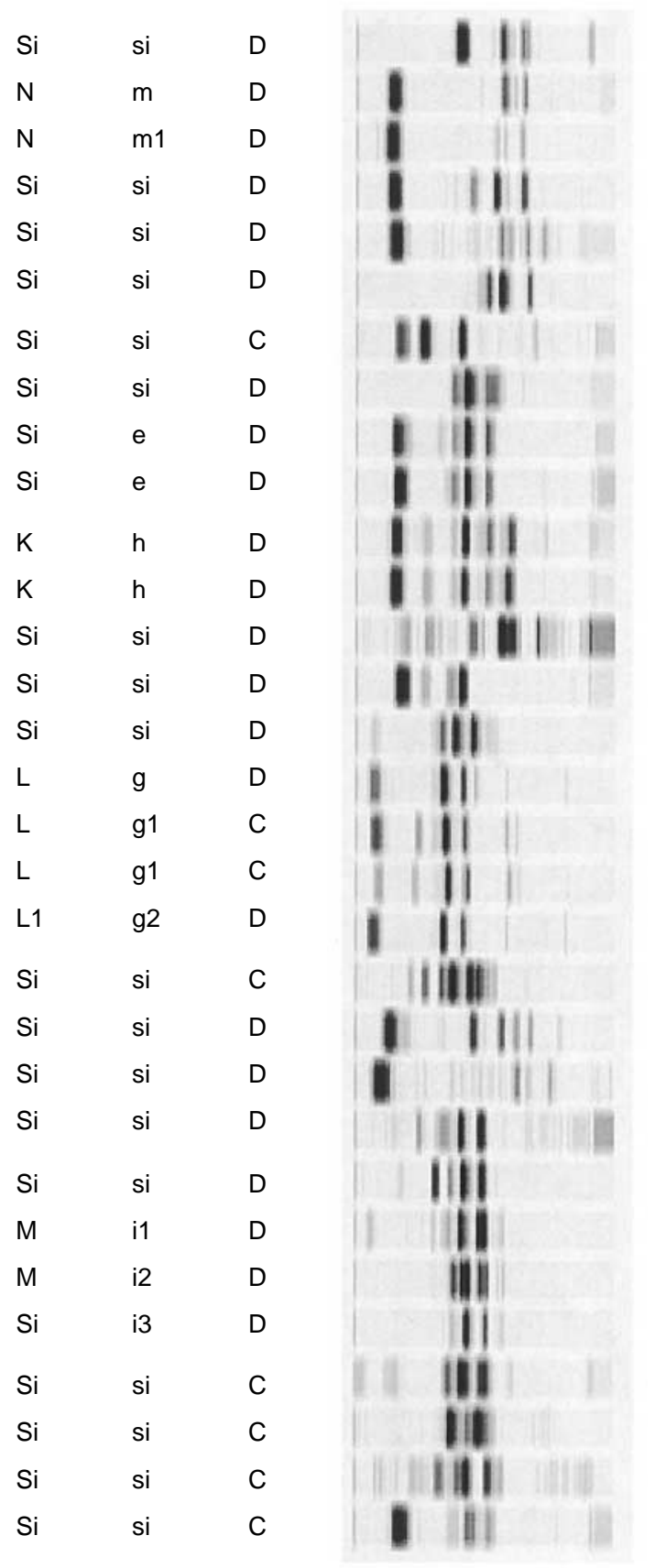

Fig. 4. UPGMA dendrogram derived from clustering of the PhP types and their comparison with $P C R$ types of $O$ antigen non-typable (ONT) EPEC strains, isolated from case-control studies of diarrhoea in Bangladesh. D, diarrhoeal case; C, healthy control; ID level, identity level; Si, PhP type found in only one isolate; si, PCR type found in only one isolate.

specific probes and cell culture assays. Non-typable EPEC strains with EAF and $A E$ properties have occasionally been isolated from cases of diarrhoea $[11,37,38]$, although their role as true pathogens in diarrhoeal disease is not known. The presence of such a high percentage of ONT EPEC strains in the present study is rather surprising. One possibility is that these strains had been true traditional EPEC serogroups and have gone through changes in their LPS content, or that they had been members of normal flora which have acquired virulence properties, as exchange of genetic material among gut flora is common [39]. The fact that these strains were isolated with high frequency from both the patients and controls and also the finding that they were of highly diverse PhP/PCR types support this hypothesis. Moreover, most ONT strains did not show any phenotypic or genotypic similarity to any of the strains of the known serogroups, ruling out the possibility that they could represent newly emerged clones of EPEC in this country. 


\section{Correlation coefficient}

0.8

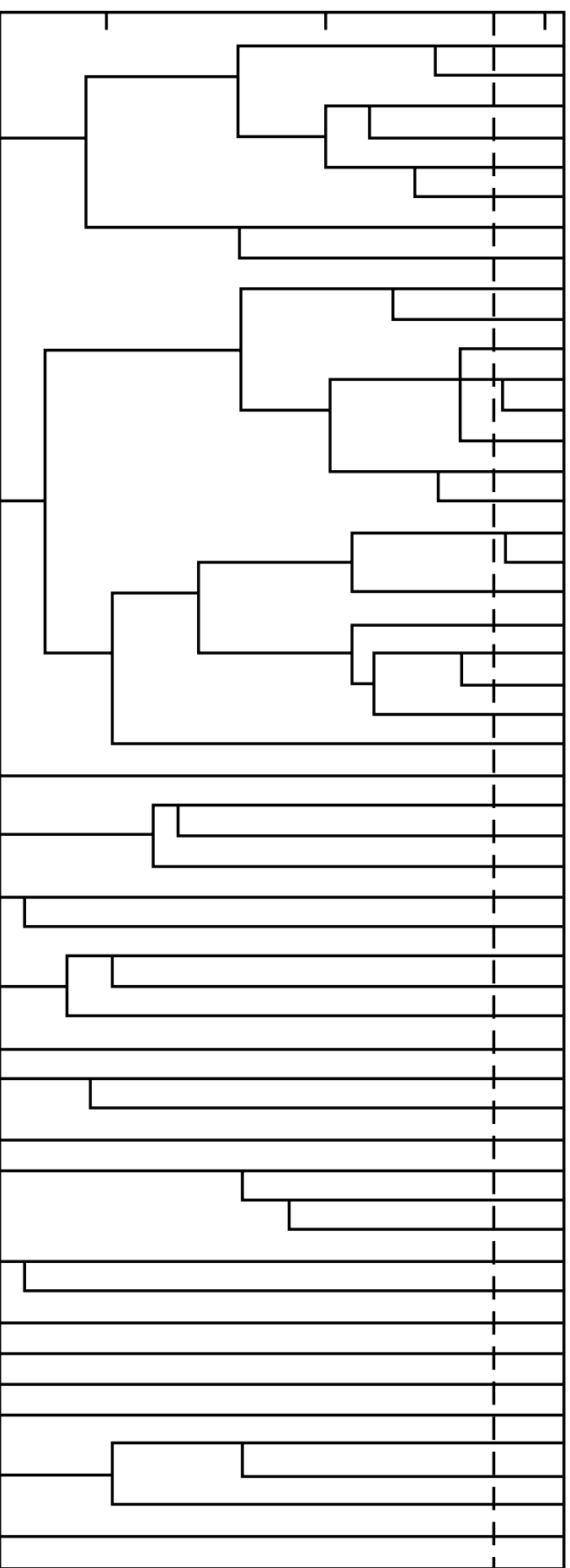

Sero

type number $\quad \mathrm{PhP}$

of isolates type

$\begin{array}{lll}0127 & 14\end{array}$

$\begin{array}{lll}0127 & 1 & \text { C3 }\end{array}$

$\begin{array}{lll}0127 & 2 & A\end{array}$

O127 2 B

$0125 \quad 1^{*} \quad 11$

O125 4 I

NT $\quad 2^{*} \quad \mathrm{~K}$

$0125 \quad 1^{*} \quad S$

$\begin{array}{lll}\text { NT } & 1 & \text { Si }\end{array}$

$\begin{array}{lll}0114 & 1 & \mathrm{Si}\end{array}$

$\begin{array}{lll}0114 & 1 & S\end{array}$

$\begin{array}{lll}\text { NT } & 2 & \text { N }\end{array}$

O128, $119 \quad 2 \quad \mathrm{E}$

$\begin{array}{lll}0126 & 1 & \mathrm{Si}\end{array}$

$\begin{array}{lll}0142 & 1 & F 1\end{array}$

$\begin{array}{lll}0142 & 1 & F 2\end{array}$

O126, $20 \quad 2^{*} \quad G$

$\begin{array}{lll}\text { NT } & 1 & \text { Si }\end{array}$

$\begin{array}{lll}\text { NT } & 1 & \text { Si }\end{array}$

O20 $2 \quad \mathrm{H} 1, \mathrm{H} 2$

NT $\quad 4^{*} \quad$ L

O44 11

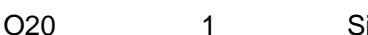

$\begin{array}{lll}\text { NT } & 1 & \text { Si }\end{array}$

$\begin{array}{lll}0114 & 1 & \mathrm{Si}\end{array}$

$\begin{array}{lll} & 114 & 16\end{array}$

$\begin{array}{lll}\text { NT } & 1 & \text { Si }\end{array}$

$\begin{array}{lll}\text { NT } & 1 & \text { Si }\end{array}$

O127 4

NT $\quad 1^{*} \quad \mathrm{Si}$

$\begin{array}{lll}\text { NT } & 1 & \text { Si }\end{array}$

$\begin{array}{lll}\text { NT } & 1 & \text { Si }\end{array}$

NT $\quad 1^{*} \quad$ Si

$\begin{array}{lll}\mathrm{O} 28 & 1 & \mathrm{Si}\end{array}$

$\begin{array}{lll}\text { NT } & 1 & \text { Si }\end{array}$

$\begin{array}{lll}\text { NT } & 1^{*} & \mathrm{Si}\end{array}$

$\begin{array}{lll}\mathrm{NT} & 1 & \mathrm{Si}\end{array}$

$\begin{array}{lll}\text { NT } & 1 & \text { Si }\end{array}$

$\begin{array}{lll}\text { NT } & 1 & \text { Si }\end{array}$

O2 1

NT $\quad 1^{*} \quad \mathrm{Si}$

$\begin{array}{lll}\text { NT } & 1 & \text { Si }\end{array}$

NT $\quad 1^{*} \quad \mathrm{Si}$

NT $\quad 1^{*} \quad \mathrm{Si}$

$\begin{array}{lll}\text { NT } & 1 & \text { Si }\end{array}$

$\begin{array}{lll} & 126 & 1\end{array}$

$\begin{array}{lll}\text { NT } & 1 & \text { Si }\end{array}$

$\begin{array}{lll}\text { NT } & 2\end{array}$

$\begin{array}{lll}0119 & 1 & \mathrm{Si}\end{array}$

$\begin{array}{lll}\text { NT } & 1 & \mathrm{Si}\end{array}$

${ }^{*}$ control isolates

Fig. 5. UPGMA dendrogram derived from clustering of all PhP types identified in the present study, with the corresponding serogrouping and PCR typing data added. One isolate representing each common and single PhP type (see Figs. 1-4) was included. ID level, identity level; ONT, 0 -antigen non-typable; Si, PhP type found in only one isolate; si, PCR type found in only one isolate.

In conclusion, two groups of EPEC strains, belonging to serogroups 0114 and 0127 , were found to be responsible for the majority of the EPEC diarrhoea in Bangladesh. The prevalence of these serogroups in this country differs from that found in other parts of the world. A high proportion of ONT EPEC strains was also found, which were of diverse clonal groups and probably have evolved from non-pathogenic clones of $E$. coli by acquiring the EPEC virulence determinants. 
This research was supported by SAREC/SIDA (grant no. INT-ICDDR, $\mathrm{B}-\mathrm{HN} / 02$ ) and the International Centre for Diarrhoeal Disease Research, Bangladesh (ICDDR,B). The ICDDR, $B$ is supported by the aid agencies of the Governments of $A$ ustralia, $B$ angladesh, B elgium, Canada, Japan, the Netherlands, Norway, Saudi A rabia, Sri Lanka, Sweden, Switzerland, the UK and the USA ; international organisations including the A rab Gulf Fund, A sian Development Bank, European Union, the United Nations Children's Fund (UNICEF), the United Nations Development Program (UNDP) and the World Health Organization (WHO); private foundations including Aga Khan Foundation, Child Health Foundation, Ford Foundation, Population Council, Rockefeller Foundation, Thrasher Foundation and the George $M$ ason Foundation; and private organisations including East-West Inc., Helen Keller International, International Atomic Energy Centre, Lederle Praxis, N ew England M edical Centre, Procter Gamble, RAND Corporation, Social Development Centre of Philippines, Swiss Red Cross, the Johns Hopkins University, the University of Alabama at Birmingham, UCB Sidac, Wander A.G. and others.

We thank Mr Manzurul Haque for secretarial assistance

\section{R eferences}

1. Kyung-Hee K, Inn-Soo S, Jung Mogg K, Choon Won K, YangJacho C. Etiology of childhood diarrhea in Korea. J Clin Microbiol 1989; 27: 1192-1196.

2. Senerwa D, Olsvik O, Mutanda LN et al. Enteropathogenic Escherichia coli serotype 0111:HNT isolated from preterm neonates in Nairobi, K enya. J C lin M icrobiol 1989; 27: 1307-1311.

3. Snyder JD, Merson MH. The magnitude of the global problem of acute diarrhoeal disease: a review of active surveillance data. Bull World Health Organ 1982; 60: 605-613.

4. Faruque SM, Haider $\mathrm{K}, \mathrm{Albert} \mathrm{MJ}$ et al. A comparative study of specific gene probes and standard bioassays to identify diarrhoeagenic Escherichia coli in paediatric patients with diarrhoea in Bangladesh. J Med Microbiol 1992; 36: 37-40.

5. Cravioto A, Reyes RE, Ortega R, Fernández G, Hernández R, López D. Prospective study of diarrhoeal disease in a cohort of rural M exican children: incidence and isolated pathogens during the first two years of life. E pidemiol Infect 1988; 101: 123- 134.

6. Echeverria $P$, Serichantalerg 0 , Changchawalit $S$ et al. Tissue culture-adherent Escherichia coli in infantile diarrhea. J Infect Dis 1992; 165: 141-143.

7. Levine MM, Ferreccio $C$, Prado $V$ et al. Epidemiologic studies of Escherichia coli diarrheal infections in a low socioeconomic level peri-urban community in Santiago, Chile. Am J Epidemiol 1993; 138: 849-869.

8. Echeverria P, Taylor DN, Lexsomboon $U$ et al. Case-control study of endemic diarrheal disease in Thai children. J Infect Dis 1989; 159: $543-548$.

9. Levine MM. Escherichia coli that cause diarrhea: enterotoxigenic, enteropathogenic, enteroinvasive, enterohemorrhagic, and enteroadherent. J Infect Dis 1987; 155: 377- 389.

10. Brown JE, Echeverria P, Taylor $D N$ et al. Determination by DNA hybridization of Shiga-like-toxin-producing Escherichia coli in children with diarrhea in Thailand. J Clin Microbiol 1989; 27: 291-294.

11. Robins-Browne RM. Traditional enteropathogenic Escherichia coli of infantile diarrhea. Rev Infect Dis 1987; 9: 28-53.

12. Bouzari S, Varghese A. Cytolethal distending toxin (CLDT) production by enteropathogenic Escherichia coli (EPEC). FEMS Microbiol Lett 1990; 71: 193-198.

13. Echeverria P, Ørskov F, Ørskov I et al. Attaching and effacing enteropathogenic Escherichia coli as a cause of infantile diarrhea in Bangkok. I Infect Dis 1991; 164: 550-554.

14. Jerse $A E, Y u J$, Tall $B D, K$ aper JB. $A$ genetic locus of enteropathogenic Escherichia coli necessary for the production of attaching and effacing lesions on tissue culture cells. Proc Natl Acad Sci USA 1990; 87: 7839-7843.

15. Knutton $\mathrm{S}$, Baldwin T, Williams $\mathrm{PH}, \mathrm{McN}$ eish AS. Actin accumulation at sites of bacterial adhesion to tissue culture cells: basis of a new diagnostic test for enteropathogenic and enterohemorrhagic Escherichia coli. Infect Immun 1989; 57: 1290- 1298.

16. Albert MJ, Faruque SM, Faruque ASG et al. Controlled study of Escherichia coli diarrheal infections in Bangladeshi children. J Clin Microbiol 1995; 33: 973-977.

17. Johnson WM, Lior H. A new heat-labile cytolethal distending toxin (CLDT) produced by Escherichia coli isolates from clinical material. Microbiol Pathol 1988; 4: 103-113.

18. A lbert MJ, Faruque SM, Faruque ASG et al. Controlled study of cytolethal distending toxin-producing Escherichia coli infections in Bangladeshi children. J Clin Microbiol 1996; 34: 717-719.

19. Versalovic J, Koeuth T, Lupski JR. Distribution of repetitive DNA sequences in eubacteria and application to fingerprinting of bacterial genomes. Nucleic Acids Res 1991; 19: 6823-6831.

20. Tenover FC, Arbeit RD, Goering RV et al. Interpreting chromosomal DNA restriction patterns produced by pulsedfield gel electrophoresis: criteria for bacterial strain typing. J Clin Microbiol 1995; 33: 2233-2239.

21. Kühn I. Biochemical fingerprinting of Escherichia coli: simple method for epidemiological investigations. J Microbiol M ethods 1985; 3: 159-170.

22. Sneath PHA, Sokal RR. Numerical taxonomy: the principles and practice of numerical classification. San Francisco, WH Freeman. 1973.

23. Katouli $M$, Jaafari $A$, Ketabi GR. The role of diarrhoeagenic Escherichia coli in acute diarrhoeal diseases in Bandar-Abbas, Iran. J Med Microbiol 1988; 27: 71-74.

24. Hunter PR, Gaston MA. Numeric index of the discriminatory ability of typing systems: an application of Simpson's index of diversity. J Clin Microbiol 1988; 26: 2465-2466.

25. Kühn I, Burman LG, Haeggman S, Tullus K, Murray BE. Biochemical fingerprinting compared with ribotyping and pulsed-field gel electrophoresis of DNA for epidemiological typing of enterococci. J Clin Microbiol 1995; 33: 2812-2817.

26. Kaper JB. M olecular pathogenesis of enteropathogenic Escherichia coli. In: Miller VL, Kaper JB, Portnoy DA, Isberg RR (eds) Molecular genetics of bacterial pathogens. Washington, DC, A SM Press. 1994: 173- 195.

27. Selander RK, Caugant DA, Ochman H, Musser JM, Gilmour $\mathrm{MH}$, Whittam TS. Method of multilocus enzyme electrophoresis for bacterial population genetics and systematics. Appl Environ Microbiol 1986; 51: 873-884.

28. Strockbine NA, Faruque SM, Kay BA et al. DNA probe analysis of diarrheagenic Escherichia coli detection of EAFpositive isolates of traditional enteropathogenic $E$. coli serotypes among Bangladeshi paediatric diarrhoea patients. Mol Cell Probes 1992; 6: 93- 99.

29. Trabulsi LR, Campos LC, Whittam TS, Gomes TAT, Rodrigues J, Goncalves AG. Traditional and non-traditional enteropathogenic Escherichia coli serogroups. Rev Microbiol Sao Paulo 1996; 27: 1-6.

30. Smith HR, Scotland SM, Cheasty T, Willshaw GA, Rowe B. Enteropathogenic Escherichia coli infections in United Kingdom. Rev Microbiol 1996; 27: 45-49.

31. Cheetham BF, Katz ME. A role for bacteriophages in the evolution and transfer of bacterial virulence determinants. Mol Microbiol 1995; 18: 201-208.

32. Mecsas J, Strauss EJ. Molecular mechanisms of bacterial virulence: type III secretion and pathogenicity islands. Emerg Infect Dis 1996; 2: 270-288.

33. Whittam TS, MCGraw EA. Clonal analysis of EPEC serogroups. Rev Microbiol Sao Paulo 1996; 27: 7-16.

34. Ørskov F, Whittam TS, Cravioto A, Ørskov I. Clonal relationships among classic enteropathogenic Escherichia coli (EPEC) belonging to different 0 groups. J Infect $D$ is 1990; 162: 76-81.

35. Campos LC, Whittam TS, Gomes TAT, Andrade JRC, Trabulsi LR. Escherichia coli serogroup 0111 includes several clones of diarrheagenic strains with different virulence properties. Infect Immun 1994; 62: 3282- 3288.

36. Whittam TS, Wolfe ML, Wachsmuth IK, Ørskov F, Ørskov I Wilson RA. Clonal relationships among Escherichia coli strains that cause hemorrhagic colitis and infantile diarrhea. Infect Immun 1993; 61: 1619-1629.

37. Albert MJ, Alam K, Ansaruzzaman $M$ et al. Localized adherence and attaching-effacing properties of nonenteropathogenic serotypes of Escherichia coli. Infect Immun 1991; 59: 1864- 1868.

38. Pedroso MZ, Freymüller $E$, Trabulsi LR, Gomes TAT. Attaching-effacing lesions and intracellular penetration in HeLa cells and human duodenal mucosa by two Escherichia coli strains not belonging to the classical enteropathogenic $E$. coli serogroups. Infect Immun 1993; 61: 1152-1156.

39. Reeves $P$. Role of 0 -antigen variation in the immune response. Trends Microbiol 1995; 3: 381-386. 